\title{
Assessment of Heavy Metal Contents of End-Of-Life Computer Monitor Cathode Tubes and Plastic Casings
}

\author{
${ }^{* 1,2}$ OWOSO, J; ${ }^{2}$ OSIBANJO, O; ${ }^{3}$ NNOROM, IC \\ ${ }^{I}$ Department of Chemical Science, Yaba College of Technology, Lagos, Nigeria. \\ *Email:jokotade1@gmail.com \\ ${ }^{2}$ Department of Chemistry, University of Ibadan, Ibadan, Nigeria.Email: oosibanjo@yahoo.com \\ ${ }^{3}$ Environmental Chemistry Unit, Department of Pure and Industrial Chemistry, Abia State University, Uturu, Abia State, Nigeria, Email: \\ nnoromicabsu@gmail.com
}

\begin{abstract}
Development and innovation in computer technology have led to the generation of large quantities of end-of-life computing equipment with the attendant challenge of environmentally sound management, especially in developing countries. This study evaluated the heavy metal contents of the cathode ray tube (CRT) and the plastic casing of thirty (30) end-of-life computer monitors of different brands, years of manufacture (spanning 1981-2005) and countries of manufacture. The specimens were analysed for $\mathrm{Pb}, \mathrm{Cu}, \mathrm{Cr}, \mathrm{Zn}, \mathrm{Cd}$, and $\mathrm{Ni}$ using atomic absorption spectrophotometer after acid digestion. The mean concentrations of metals in the CRTs varied widely: 1400-14300 $\mathrm{mg} / \mathrm{kg}$ for $\mathrm{Pb} ; 291-1750 \mathrm{mg} / \mathrm{kg}$ for $\mathrm{Zn} ;<0.1-129 \mathrm{mg} / \mathrm{kg}$ for $\mathrm{Cu} ;<0.1-15 \mathrm{mg} / \mathrm{kg}$ for $\mathrm{Ni} ;<0.1-16.3 \mathrm{mg} / \mathrm{kg}$ for $\mathrm{Cr}$, and $<0.1-4.0 \mathrm{mg} / \mathrm{kg}$ for $\mathrm{Cd}$. The $\mathrm{Pb}$ concentrations of all the CRT samples, with mean $5120 \pm 3000 \mathrm{mg} / \mathrm{kg}$ (range: 1400 $14300 \mathrm{mg} / \mathrm{kg}$ ), exceeded the $1000 \mathrm{mg} / \mathrm{kg}$ Pb limit in the EU Directive on the Restriction of Hazardous Substances (RoHS) and the Total Threshold Limit Concentrations (TTLC) used by the USA Department of Toxic Substances and Control (DTSC), for characterizing waste as hazardous. For the plastic casings, the $\mathrm{Cu}$ and $\mathrm{Cd}$ concentrations in $10 \%$ and $20 \%$ of the samples respectively, exceeded the TTLC. The results of this study show that the CRTs are hazardous waste requiring environmentally sound management and the crude methods of management in Nigeria which include disposal at open dumpsites and surface water, as well as recycling using crude techniques are highly dangerous, exposing man and the ecosystem to toxins.
\end{abstract}

DOI: https://dx.doi.org/10.4314/jasem.v22i3.19

Copyright: Copyright $\left({ }^{\circ} 2018\right.$ Owoso et al. This is an open access article distributed under the Creative Commons Attribution License (CCL), which permits unrestricted use, distribution, and reproduction in any medium, provided the original work is properly cited

Dates: Received: 23 January 2018; Revised: 26 February: 2018; Accepted: 18 March 2018

Keywords: environmental hazard, cathode ray tube, plastic casing, end-of-life, computer monitor

End-of-life (EoL) is a stage in the life of a product when it becomes dysfunctional to the owner or user, thereby becoming waste (ITU, 2012). Large quantities of used electrical and electronic equipment (UEEE) are exported to developing countries annually (Ogungbuyi et al., 2012). Recent publication of Odeyingbo et al. (2017) showed the extent of used and waste electronics exports into Nigeria from Europe, USA and other Asian countries especially China. Well trained technicians repair high percentage of the non-functional UEEE while the unrepairable devices are disassembled and the valuable components used in repairs (Owoso, 2016). This has led to a large build-up of waste electrical and electronic equipment (WEEE) from importation and local generation of over a million tonnes of which $21.5 \%$ is from ICT equipment (Ogungbuyi et al., 2012). Computers have been known to contain potentially hazardous substances such as heavy metals $(\mathrm{Hg}, \mathrm{Pb}, \mathrm{Cr}$ and $\mathrm{Cd})$ and brominated flame retardants (BFRs) such as polybrominated diphenylethers (PBDEs) which can pollute the environment, when not properly managed (Kaya, 2016). Though e-waste composition is changing with technological development and restrictions by laws that regulate the use of hazardous substances in EEE, such as the European Union (EU) Directive on Restriction of Hazardous Substances (RoHS), the old equipment entering the waste stream still contain these toxic materials. The management of WEEE components such as cathode ray tubes (CRTs) has therefore become a matter of global environmental concern as a result of the increasing volumes being generated and the hazardous contents of the components (Yao et al., 2017; Iniaghe and Adie, 2015).

Cathode ray tube, the technology used in most televisions and computer monitors has been identified as the main source of $\mathrm{Pb}$ in electronics (Musson et al., 2000; Nnorom et al., 2010). Lead is found mainly as $\mathrm{PbO}$ in the leaded glass used for the neck and funnel and in the lead-solder glass called frit that is used to join the different parts of the funnel. Rapid 
development in computer technology led to the replacement of CRT with newer and advanced technologies such as liquid crystal display (LCD) which will reduce $\mathrm{Pb}$ concentration in WEEE, but LCD also contains metals such as $\mathrm{Hg}, \mathrm{Zn}, \mathrm{Sn}$ (Robinson, 2009). The plastics casing of computer monitor consists of polymers treated with brominated flame retardants (BFRs) such as polybrominated biphenyls (PBBs) and polybrominated diphenylethers (PBDEs) often combined with $\mathrm{Sb}_{2} \mathrm{O}_{3}$ as synergist (Dimitrakakis et al., 2009); as well as inorganic additives such as $\mathrm{TiO}_{2}, \mathrm{ZnO}, \mathrm{Cr}_{2} \mathrm{O}_{3}$, and $\mathrm{Fe}_{2} \mathrm{O}_{3}$ which form part of pigments as well as compounds of $\mathrm{Ba}$, $\mathrm{Cd}, \mathrm{Pb}, \mathrm{Zn}$ and $\mathrm{Sn}$ that are components of stabilizers or plasticizers (Dimitrakakis et al., 2009). This study assessed the potential environmental hazard of waste computer monitors by determining the heavy metal contents of the CRTs and plastic casings of computer monitors of different brands, years of manufacture and countries of manufacture. The potential hazard posed by computer monitors studied was assessed by comparing the results of this study with hazardous waste regulatory thresholds.

\section{MATERIALS AND METHODS}

Collection and preparation of sample: Thirty EoL computer monitors of different brands, models and manufacturers were collected from electronic repair workshops, households and corporate users in Lagos. Each monitor was dismantled using stainless steel hand tools such as screwdrivers, pliers and hammer to obtain the cathode ray tube (CRT) and the plastic casing. Information such as brand, manufacturer, model number, serial number and year and country of manufacture indicated on each device were recorded. The glass seal at the cathode connection point of the CRT was carefully broken to release the vacuum. Furthermore, the CRT was separated into its three main parts i.e. the neck, the funnel and the face panel, by carefully breaking each part with hammer.

The CRT glass and plastic casing were separately size-reduced by crushing and cutting with cleaned stainless steel tools such as, hammer, saw and shearer and then ground with a locally fabricated hammer mill. The mill was cleaned after grinding each component by passing dried wood chips that have been pre-washed with $5 \%$ nitric acid through it, to serve as blank to assess cross contamination (Olubanjo et al., 2015). To avoid memory effect, blast pressurized air was pumped through the mill. The milled sample was sieved with a $2 \mathrm{~mm}$ stainless steel sieve. The $<2 \mathrm{~mm}$ particle sized samples were thoroughly mixed and sealed in appropriately labeled polyethylene package and kept for analysis. For the CRT glass, $10 \mathrm{~g}$ each of the $<2 \mathrm{~mm}$ particle size samples of the neck, funnel and face panel glass of each CRT was weighed, thoroughly mixed together and homogenized to obtain the laboratory sample for each CRT. This process was to ensure that a representative sample composed of the three main parts of the CRT was used for the analysis.

The distribution of the year of manufacture of the computer CRT and plastic casing is presented in Table 1. Most of the samples were manufactured in the period 1995-2002; years before the enactment of the RoHS Directive in 2006. The distribution of the samples according to their country of manufacture is shown in Table 2.

Table 1. Year of manufacture of the studied computer monitors

\begin{tabular}{lcc}
\hline \multicolumn{3}{c}{ (CRT and plastic casing) } \\
\hline Year & $\begin{array}{c}\text { Number } \\
\text { of CRTs }\end{array}$ & $\begin{array}{c}\text { Number of } \\
\text { Plastic casings }\end{array}$ \\
\hline $1979-1982$ & 1 & - \\
$1983-1986$ & - & - \\
$1987-1990$ & 9 & 5 \\
$1991-1994$ & 2 & 1 \\
$1995-1998$ & 9 & 12 \\
$1999-2002$ & 4 & 6 \\
$2003-2006$ & 3 & 3 \\
Year not indicated & 2 & 3 \\
Total & 30 & 30 \\
\hline
\end{tabular}

Table 2. Country of origin of the studied computer monitors (CRT

\begin{tabular}{lcc}
\multicolumn{3}{c}{ and plastic casing) } \\
$\begin{array}{lcc}\text { Country of } \\
\text { manufacture }\end{array}$ & $\begin{array}{c}\text { Number } \\
\text { of CRTs }\end{array}$ & $\begin{array}{c}\text { Number of } \\
\text { Plastic casings }\end{array}$ \\
\hline China & 9 & 13 \\
Korea & 8 & 3 \\
Malaysia & 3 & 4 \\
Taiwan & 4 & 1 \\
Thailand & 1 & 1 \\
Japan & 1 & - \\
Indonesia & - & 1 \\
UK & - & 2 \\
Austria & 2 & - \\
Hungary & - & 1 \\
Mexico & - & 1 \\
Country not & 2 & 3 \\
indicated & & 30 \\
Total & 30 & \\
\hline
\end{tabular}

Approximately $87 \%$ of the CRT samples were manufactured in Asia with about $35 \%$ of them made in China. Most of the computer monitor plastic casings $(77 \%)$ were also manufactured in Asia with more than half of them made in China (Table 2).

Digestion and analysis of sample: The EPA SW-846 Method 3050B was adopted for the digestion of the CRT samples, with some slight modifications as reported by Nnorom et al. (2010). One-gram of each sample was weighed into a $250 \mathrm{~mL}$ Erlenmeyer flask and $10 \mathrm{~mL}$ 1:1 $\mathrm{HNO}_{3}$ (65 \%; BDH Laboratory Supplies, Poole, England):de-ionised water added to the sample to make a slurry. This was digested on a 
hot plate for about 15 minutes and allowed to cool. 5 $\mathrm{mL}$ of concentrated $\mathrm{HNO}_{3}$ was then added and the solution heated for another 30 minutes and allowed to cool. This step was repeated until no brown fumes were given off. The sample was then heated at $95{ }^{\circ} \mathrm{C}$ without boiling for one hour. After cooling the sample, $2 \mathrm{~mL}$ of deionized water and $3 \mathrm{~mL}$ of $30 \%$ $\mathrm{H}_{2} \mathrm{O}_{2}$ (BDH Laboratory Supplies, Poole UK) was added and the flask returned to the hot plate for warming and to start the peroxide reaction, care being taken to ensure that losses do not occur due to excessive vigorous effervescence. The heating was continued until the general sample appearance remained unchanged or more $\mathrm{H}_{2} \mathrm{O}_{2}$ (not exceeding a total of $10 \mathrm{~mL}$ for each sample) was added until no colour change was observed. The sample was further heated at $95{ }^{\circ} \mathrm{C}$ without boiling until the sample solution was reduced to about $5 \mathrm{~mL}$. After allowing the sample digest to cool, $10 \mathrm{~mL}$ concentrated $\mathrm{HCl}$ (37\%, BDH Laboratory Supplies) was added and the digest heated at $95{ }^{\circ} \mathrm{C}$ until the brown fumes have disappeared. The sample digest was allowed to cool, filtered into a $100 \mathrm{~mL}$ volumetric flask and diluted to mark with deionised water. The solutions of the digest were analysed for $\mathrm{Cd}, \mathrm{Cr}, \mathrm{Pb}, \mathrm{Cu}, \mathrm{Ni}, \mathrm{Zn}$ using flame atomic absorption spectrophotometer (AAnalyst 200, Perkin Elmer, Waltham, USA).

The samples of all the plastic casing of computer monitors were digested using the method adopted by Nnorom and Osibanjo (2009) and Nnorom et al. (2010) for the analysis of plastics of waste mobile phone and computer monitors respectively. $10 \mathrm{~mL}$ of 1:1 mixture of $\mathrm{H}_{2} \mathrm{SO}_{4}(97 \%): \mathrm{HNO}_{3}(65 \%)$ was added to one-gram sample in a $250 \mathrm{~mL}$ Erlenmeyer flask and the sample digested at $120^{\circ} \mathrm{C}$ on a hot plate to near dryness. The digest was re-solubilised with 10 $\mathrm{mL}$ deionised water, filtered into a $100 \mathrm{~mL}$ volumetric flask and made up to the mark with deionised water. Blank samples were prepared using the same procedure. The solutions of the digest were analysed for $\mathrm{Cd}, \mathrm{Cr} \mathrm{Pb}, \mathrm{Cu}, \mathrm{Ni}$, and $\mathrm{Zn}$ by flame atomic absorption spectrophotometer (AAnalyst 200, Perkin Elmer).

Quality control/assurance: To ensure the reliability of results, all the glass wares and containers used were soaked and washed with liquid detergent, rinsed with tap water, soaked in an acid bath of $5 \% \mathrm{HNO}_{3}$, rinsed severally with tap water and finally rinsed thoroughly with deionised water. The cleaned glass wares were then oven dried and stored. All reagents $\left(\mathrm{HNO}_{3}, \mathrm{H}_{2} \mathrm{O}_{2}, \mathrm{HCl}, \mathrm{H}_{2} \mathrm{SO}_{4}\right)$ were of analytical grade especially from BDH Laboratory Supplies (Poole, England). Quality assurance samples (blanks and duplicate analysis) were included. Percentage recovery was determined by spiking known amount of the sample prior to digestion and analysis with predetermined quantity of standard solutions of the analytes. Within-sample and between-samples replicates were taken through the digestion procedure. Ten replicates of one brand of plastic casing of computer monitor were analysed for withinsample variability, and five samples each of three different brands of plastic casings for betweensamples variability.

\section{RESULTS AND DISCUSSION}

The metal concentrations in the CRT samples varied from $1400-14300 \mathrm{mg} / \mathrm{kg}$ (mean $5120 \pm 3000 \mathrm{mg} / \mathrm{kg}$ ) for $\mathrm{Pb} ; 291-1750 \mathrm{mg} / \mathrm{kg}$ (mean $788 \pm 370 \mathrm{mg} / \mathrm{kg}$ ) for $\mathrm{Zn}$; $<0.1-129 \mathrm{mg} / \mathrm{kg}$ (mean $8.29 \pm 23 \mathrm{mg} / \mathrm{kg}$ ) for $\mathrm{Cu}$; $<0.1-16.3 \mathrm{mg} / \mathrm{kg}$ (mean $3.97 \pm 4.3 \mathrm{mg} / \mathrm{kg}$ ) for $\mathrm{Cr}$; $<0.1-15.0 \mathrm{mg} / \mathrm{kg}$ (mean $3.37 \pm 3.3 \mathrm{mg} / \mathrm{kg}$ ) for $\mathrm{Ni}$; and $<0.1-4.0 \mathrm{mg} / \mathrm{kg}$ (mean $0.567 \pm 1.2 \mathrm{mg} / \mathrm{kg}$ ) for $\mathrm{Cd}$ (Table 3). These results are comparable to the values of $1271 \pm 918 \mathrm{mgPb} / \mathrm{kg}$ (range $645-2892 \mathrm{mgPb} / \mathrm{kg}$ ), $22.3 \pm 9.06 \mathrm{mgCu} / \mathrm{kg}$ (range: $<0.1-32.5 \mathrm{mgCu} / \mathrm{kg}$ ), $49.9 \pm 27 \mathrm{mgCr} / \mathrm{kg}(18.4-91.2 \mathrm{mgCr} / \mathrm{kg})$ reported by Nnorom et al. (2010); and the concentrations of $4340.8 \mathrm{mgPb} / \mathrm{kg}$ (range $429-9900 \mathrm{mgPb} / \mathrm{kg}$ ) and $165.83 \mathrm{mgCu} / \mathrm{kg}$ (range $73.2-468 \mathrm{mgCu} / \mathrm{kg}$ ) reported by Olubanjo et al. (2015). Available literature show that the main source of $\mathrm{Pb}$ in the CRT is the $\mathrm{PbO}$ present in the funnel and neck glass; and in the leadsolder glass (frit) used to join the different parts of the funnel, which contain $24 \%, 30 \%$ and $70 \% \mathrm{~Pb}$ respectively; while the face panel contains $0-3 \% \mathrm{~Pb}$ (Musson et al., 2000).

The metal concentrations in the plastic casings varied from $34.5-599 \mathrm{mg} / \mathrm{kg}$ for $\mathrm{Zn}$ (mean $182 \pm 163 \mathrm{mg} / \mathrm{kg}$ ), $<0.1-51 \mathrm{mg} / \mathrm{kg}$ (mean $19.8 \pm 13 \mathrm{mg} / \mathrm{kg}$ ) for $\mathrm{Cr} ;<0.1$ $295 \mathrm{mg} / \mathrm{kg}$ (mean $55.9 \pm 74.0 \mathrm{mg} / \mathrm{kg}$ ) for Cd; $13.7-281$ $\mathrm{mg} / \mathrm{kg}$ (mean $115 \pm 68 \mathrm{mg} / \mathrm{kg}$ ) for $\mathrm{Pb} ; 4.35-3680$ $\mathrm{mg} / \mathrm{kg}$ (mean $564 \pm 963 \mathrm{mg} / \mathrm{kg}$ ) for $\mathrm{Cu}$ and $6.10-97$ $\mathrm{mg} / \mathrm{kg}$ (mean $52.4 \pm 23.0 \mathrm{mg} / \mathrm{kg}$ ) for Ni (Table 4). The mean concentrations were in the order $\mathrm{Cu}>>\mathrm{Zn}>\mathrm{Pb}>\mathrm{Cd}>\mathrm{Ni}>\mathrm{Cr}$. The high standard deviation values could be due to the uneven distribution of the heavy metals in the sample arising from the intrinsic non-homogeneity of the grinded sample materials as indicated by the value of the precision calculated as coefficient of variation of the replicate analysis for testing within- sample and between-sample heterogeneity for the plastic casings which gave the following results: Within-sample replicate- $32.7 \%$ for $\mathrm{Zn}$; $64.3 \%$ for $\mathrm{Cr} ; 39.0 \%$ for $\mathrm{Cd} ; 24.7 \%$ for $\mathrm{Pb} ; 17.3 \%$ for $\mathrm{Cu}$; and $22.2 \%$ for $\mathrm{Ni}$. Similarly high values of coefficient of variation for $\mathrm{Cd}(40 \%), \mathrm{Pb}(59 \%)$ and $\mathrm{Ni}(31 \%)$ were reported by Nnorom and Osibanjo (2009) for mobile phone 
plastics. Between-samples replicate- $49.9 \%-73.8 \%$ for $\mathrm{Zn}$; $41.5 \%-70.2 \%$ for $\mathrm{Cr} ; 34.9 \%-53.8 \%$ for $\mathrm{Pb}$; $32.8 \%-81.4 \%$ for $\mathrm{Cu}$; and $48.8 \%-89.9 \%$ for $\mathrm{Ni}$. The observed high variability in metal concentrations between plastic casings of the different brands and models may be attributable to variations from batch- to-batch inconsistencies, the unequal distribution of the metals in the samples (Nnorom and Osibanjo, 2009); as well as differences in material composition and manufacturing practices from manufacturer to manufacturer

Table 3. Summary of metal concentrations $(\mathrm{mg} / \mathrm{kg})$ of CRT components of computer monitor

\begin{tabular}{lllllll}
\multicolumn{6}{c}{ Table 3. Summary of metal concentrations $(\mathrm{mg} / \mathrm{kg})$} & of CRT components of computer monitor \\
\hline Parameter & $\mathrm{Zn}$ & $\mathrm{Cr}$ & $\mathrm{Cd}$ & $\mathrm{Pb}$ & $\mathrm{Cu}$ & $\mathrm{Ni}$ \\
\hline${ }^{\mathrm{a}}$ Mean \pm SD & $788 \pm 370$ & $3.97 \pm 4.3$ & $0.567 \pm 1.2$ & $5120 \pm 3000$ & $8.29 \pm 23$ & $3.37 \pm 3.3$ \\
Range & $291-1750$ & $<0.1-16.3$ & $<0.1-4.00$ & $1400-14300$ & $<0.1-129$ & $<0.1-15.0$ \\
Geometric Mean & 705 & 1.84 & & 4340 & 3.33 & 3.30 \\
${ }^{\mathrm{b}}$ TTLC & 5000 & 500 & 100 & 1000 & 2500 & 2000 \\
${ }^{\mathrm{c}} \mathrm{N}>\mathrm{TTLC}$ & - & - & - & 30 & - & - \\
Percentage that & - & - & - & 100 & - & - \\
exceeded TTLC & & & & & & \\
\hline
\end{tabular}

Table 4. Summary of metal concentrations $(\mathrm{mg} / \mathrm{kg})$ of plastic casings of computer monitors

\begin{tabular}{lllllll}
\hline Sample No & $\mathrm{Zn}$ & $\mathrm{Cr}$ & $\mathrm{Cd}$ & $\mathrm{Pb}$ & $\mathrm{Cu}$ & $\mathrm{Ni}$ \\
\hline a Mean \pm SD & $182 \pm 163$ & $19.8 \pm 13$ & $55.9 \pm 74$ & $115 \pm 68$ & $564 \pm 963$ & $52.4 \pm 23$ \\
Range & $34.5-599$ & $\mathrm{ND}-51$ & $\mathrm{ND}-295$ & $13.7-281$ & $4.35-3680$ & $6.10-97$ \\
Geometric mean & 129 & 15.5 & 26.7 & 95.0 & 149 & 42.7 \\
bTTLC & 5000 & 500 & 100 & 1000 & 2500 & 2000 \\
${ }^{\mathrm{c}}$ N $>$ TTLC & - & - & 6 & & 3 & - \\
Percentage that & - & - & 20 & - & 10 & - \\
exceeded TTLC & & & & & & \\
\hline ean \pm standard deviation; ${ }^{\mathrm{b}}$ Total threshold limit concentration; ${ }^{\mathrm{c}}$ Number of samples with values greater than TTLC
\end{tabular}

Metals such as $\mathrm{Zn}, \mathrm{Cr}, \mathrm{Cd}$, and $\mathrm{Pb}$ in the form of their compounds are used as additives (pigments and plasticisers or stabilizers) in the polymeric materials used for the manufacture of plastic casings (Dimitrakakis et al., 2009); and the presence of Cr, $\mathrm{Pb}, \mathrm{Cd}, \mathrm{Ti}, \mathrm{Zn}, \mathrm{Cu}$ in different types of EEE plastics have been reported from various studies (Stenvall, 2013; Nnorom et al., 2010; Nnorom and Osibanjo, 2009). Comparison of the mean metal concentrations in the samples with the maximum allowable concentrations of $1000 \mathrm{mg} / \mathrm{kg}$ for $\mathrm{Pb}$ and $\mathrm{Cr}$; and 100 $\mathrm{mg} / \mathrm{kg}$ for Cd according to the EU Directive on the Restriction of Hazardous Substances (RoHS) showed that only the $\mathrm{Pb}$ concentrations in all the CRT samples exceeded the limit while the $\mathrm{Cr}$ and $\mathrm{Cd}$ concentrations were lower than the respective RoHS limits. None of the results for $\mathrm{Pb}$ and $\mathrm{Cr}$ in plastic casings exceeded the RoHS threshold while 6 (20\%) of the samples contained $\mathrm{Cd}$ concentrations that exceeded the $100 \mathrm{mg} / \mathrm{kg}$ limit. Further comparison with the Total Threshold Limit Concentration (TTLC), the USA State of California Department of Toxic Substances Control's regulatory threshold for classifying solid waste material as hazardous shows that all the CRT samples exceeded the limit of 1000 $\mathrm{mg} / \mathrm{kg}$ for $\mathrm{Pb}$, while the concentrations of all the other metals were much lower than their respective TTLC limits (Table 3). For the plastic casings $20 \%$ and $10 \%$ of the samples contained $\mathrm{Cd}$ and $\mathrm{Cu}$ concentrations above the TTLC values of $100 \mathrm{mg} / \mathrm{kg}$ and $2500 \mathrm{mg} / \mathrm{kg}$ respectively (Table 4).
Various studies aimed at characterizing computer components using leaching tests have in most cases reported that CRTs consistently failed the Toxicity Characteristic Leaching Procedure (TCLP) tests with respect to $\mathrm{Pb}$ (Musson et al., 2000; Nnorom et al., 2010). The TCLP, a United States Environmental Protection Agency (USEPA) test used in determining whether waste may be accepted into a landfill facility, prescribes a regulatory threshold of $5 \mathrm{mg} / \mathrm{kg} \mathrm{Pb}$. Musson et al. (2000) obtained mean $\mathrm{Pb}$ concentrations of $8.6 \mathrm{mg} / \mathrm{L}$ and $75.3 \mathrm{mg} / \mathrm{L}$ respectively for the TCLP leachate of the neck and funnel glass of $36 \mathrm{CRTs}$, showing that the samples failed the TCLP test for $\mathrm{Pb}$. Furthermore, Nnorom et al. (2010) reported that of the mean $1271 \mathrm{mg} \mathrm{Pb} / \mathrm{kg}$ in computer CRT, $146 \mathrm{mg} / \mathrm{L}$ and $132 \mathrm{mg} / \mathrm{L}$ was extractable using $1 \mathrm{M}$ calcium chloride solution and deionised water as extractant respectively, values that exceeded the TCLP limit of $5 \mathrm{mg} / \mathrm{L}$ for $\mathrm{Pb}$. These findings show that with the high concentrations of $\mathrm{Pb}$ obtained for the CRTs analysed in this study, the metal can readily leach to contaminate the soil and water environment, if the CRTs are not appropriately managed as hazardous waste.

Environment Concerns: The high content of metals such as $\mathrm{Pb}$ in $\mathrm{CRT}$ poses serious threat to the environment because of the inappropriate e-waste management practices in use in Lagos, Nigeria as in other developing countries; which include manual 
dismantling without the use of personal protective equipment, breaking of CRT for recovery of valuable materials and dumping in open spaces or with municipal solid waste (Owoso, 2016). It has been noted that disposal in landfills and open spaces is not accepted as management option for CRT components because of the possibility of acid leaching of high concentrations of heavy metals to the ground (Iniaghe and Adie, 2015). Lead has also been found to leach from broken CRT glass from TV and computer monitors (Musson et al., 2000; Nnorom et al., 2010). Dismantling of CRT without the use of personal protective equipment may also expose humans (workers and residents) to health risks through inhalation of particulate lead released into the air (Lecler et al., 2015).

These e-waste management practices could result in pollution of soil and water, from the re-deposition of particulate $\mathrm{Pb}$ from the dismantling activities. Analysis of soil collected from a site of dismantling and breaking of CRT computer monitors and television set at the Alaba International Market in Lagos, Nigeria gave higher concentration of $\mathrm{Pb}(344$ $\mathrm{mg} / \mathrm{kg})$ than the other metals investigated $(\mathrm{Cu}-112$ $\mathrm{mg} / \mathrm{kg} ; \mathrm{Zn}-50.5 \mathrm{mg} / \mathrm{kg} ; \mathrm{Cr}-13.4 \mathrm{mg} / \mathrm{kg} ; \mathrm{Ni}-8.58$ $\mathrm{mg} / \mathrm{kg} ; \mathrm{Cd}-1.45 \mathrm{mg} / \mathrm{kg}$ ), attributable to the redeposition of particulate $\mathrm{Pb}$ released from the e-waste activity at the site (Owoso, 2016). The re-deposition of particulate lead and washing of $\mathrm{Pb}$ leachate from broken CRT into the soil, surface water and ground water may result in human exposure through consumption of contaminated water, crops, or direct ingestion of contaminated soil. Such effect reported about e-waste recycling workers and residents by Asante et al. (2012) showed that $\mathrm{Pb}$ concentration in the urine of e-waste recycling workers in Agbogbloshie, Ghana was significantly higher than those of workers from the reference sites. Bioaccumulation of $\mathrm{Pb}$ from repeated exposure could result to damage to the nervous system.

Some of the plastic casings analysed in this study had $\mathrm{Cu}$ and $\mathrm{Cd}$ concentrations which exceeded the TTLC (10\% and $20 \%$ respectively). This also indicated the potential for $\mathrm{Cu}$ and $\mathrm{Cd}$ pollution from WEEE plastics. The metals in the plastic components while contained within the plastic matrix do not leach and are not bioavailable (Robinson et al., 2009) but with the present practice in Nigeria of open burning to reduce waste volume (Owoso, 2016), metals in the WEEE plastics may pollute the environment through volatilization and washing of the ash resulting from burning activities along with leachates into the soil and water used for domestic purposes. Copper in the plastic can serve as catalyst for the formation of toxic dioxins and furans from brominated flame retardants in the plastic (Amfo-Otu et al., 2013). These inappropriate e-waste management practices may result in human exposure to high levels of these metals and toxins. The high $\mathrm{Pb}$ content in CRT especially the funnel glass also has economic implications as a secondary resource. Studies have shown that $\mathrm{Pb}$ recovered from waste CRT funnel glass can be used for various applications such as preparation of high silicate powders appropriate for use as catalyst carrier, semipermeable membranes, and adsorbents or re-melted into high silicate glass as an ideal substitute for quartz glass (Xing et al., 2017) and for synthesizing zeolites (Yao et al., 2017). WEEE plastics if appropriately recycled can be used as process engineering fuel in chemical feedstock recycling processes or in energy recovery systems (Nnorom and Osibanjo, 2009). In the absence of the required technology for the recycling of the WEEE plastics as is the case in Nigeria, landfilling in designated landfill that has been prepared to prevent leaching and contamination of underground water may be the best option instead of the present practice of open burning.

Conclusion: The results from this study revealed that the glass in all the CRTs contained levels of $\mathrm{Pb}$ that exceeded the limits stipulated in the Total Threshold Limit Concentration (TTLC), the United States' established regulatory limits for classifying waste as hazardous. They should therefore not be disposed indiscriminately with municipal solid waste in open dumps or unauthorised dumps. It is recommended that measures and infrastructure for the environmentally sound management of this waste stream should urgently be put in place.

Acknowledgement: The study was supported by the Tertiary Education Trust Fund (TETFUND), Nigeria through a grant to the first author.

\section{REFERENCES}

Amfo- Otu, R; Bentum, JK; Omari, S (2013). Assessment of contamination through e-waste recycling activities in Tema Community one. Environ. and Pollut. 2(2): 66-70.

Asante, KA; Agusa, T; Biney, CA; Agyekum, WA; Bello, M; Otsuka, M; Itai, T; Takahashi, S; Tanabe, S (2012). Multi-trace element levels and arsenic speciation in urine of e-waste recycling workers from Agbogbloshie, Accra in Ghana. Sci. Total Environ. 424: 63-73.

Dimitrakakis, E; Janz, A; Bilitewski, B; Gidarakos, E (2009). Determination of heavy metals and 
halogens in plastics from electrical and electronic waste. Waste Manage. 29: 2700-2706.

Iniaghe, PO; Adie, GU (2015). Management practices for end-of-life cathode ray tube glass: Review of advances in recycling and best available technologies. Waste Manage. \& Res. 33(11): 947-961.

ITU (2012). End-of-life management for ICT equipment. http://www.itu.int/dms_pub/itut/oth/4B/04/T4B0400000B0013PDFE.pdf

Kaya M (2016). Recovery of Metals and nonmetals from electronic waste by physical and chemical recycling processes. Waste Manage. 5: 64-90.

Lecler, M; Zimmermann, F; Silvente, E; Clerc, F; Chollot, A; Grosjean, J (2015). Exposure to hazardous substances in cathode ray tube (CRT) recycling sites in France. Waste Manage. 39: 226-235.

Musson SE; Jang, Y; Townsend, TG; Chung, I (2000). Characterization of lead leachability from cathode ray tubes using the Toxicity Characteristic Leaching Procedure. Environ. Sci. Technol. 34: 4376- 4381.

Nnorom, IC; Osibanjo, O (2009). Toxicity characterization of waste mobile phone plastics. J. Hazard. Mater. 161: 183- 188.

Nnorom, IC; Osibanjo, O; Okechukwu, K; Nkwachukwu, O; Chukwuma, RC (2010).

Evaluation of heavy metal release from the disposal of waste computer monitors at an open dump. Inter J. Environ. Sci. Dev. 1(3): 227-233.

Odeyingbo, O; Nnorom, IC; Deubzer, O (2017). Person-in-the-Port Project: Assessing import of used electrical and electronic in Nigeria. UNUViE SCYCLE and BCCC Africa, Bonn

Ogungbuyi, K; Nnorom IC; Osibanjo, O; Schluep, M (2012). E-Waste country assessment Nigeria. EWaste Africa Project of the Secretariat of the Basel Convention, May 2012. http://www.basel.int/Portals/4/Basel\%20Convent ion/docs/eWaste/EwasteAfrica_NigeriaAssessment.pdf

Olubanjo, K; Osibanjo, O; Nnorom IC (2015). Evaluation of $\mathrm{Pb}$ and $\mathrm{Cu}$ contents of selected components of waste personal computers. $J$. Appl. Sci. Environ. Manage. 19 (3): 470- 477.

Owoso, J (2016). Environmental impacts of e-waste activities on heavy metal contamination of selected sites in Lagos, Nigeria. Ph.D Thesis, University of Ibadan, Ibadan.

Robinson, HB (2009). E-waste: An assessment of global production and environmental Impacts. Sci. Total Environ. 408: 183-191.

Stenvall, E., Tosta, S., Boldizar, A., Foreman, MR; Möller, K, (2013). An analysis of the composition and metal contamination of plastics from waste (EEE). Waste Manage. 33: 915-922.

Xing, M; Fu, Z; Wang, Y; Wang, J; Zhang, Z (2017). Lead recovery and high silica glass powder synthesis from waste CRT funnel glasses through carbon thermal reduction enhanced glass phase separation process. J. Hazard. Mater. 32: 479487.

Yao, Z; Wu, D; Liu, J; Wu, W; Zhao, H; Tang, J (2017). Recycling of a typical difficult-to-treat ewaste: Synthesize zeolites from waste cathoderay-tube funnel glass. J. Hazard. Mater. 324: 673-680. 